Arhe XVIII, 35/2021

UDK 1 Bruno G.

DOI https://doi.org/10.19090/arhe.2021.35.225-239

Originalni naučni rad

Original Scientific Article

YANNIS FIKAS ${ }^{1}$

BCA College, Athens, Greece

\title{
GIORDANO BRUNO, HIS PLACE IN THE HISTORY OF PHILOSOPHY AND IDEAS
}

\begin{abstract}
The aim of this paper is to present the Renaissance philosopher Giordano Bruno. According to Giordano Bruno, a human being is threefold composed of a body (soma), soul (psyche) and spirit (nous). Bruno's philosophical theory on the harmonization of the soul with the mind (nous) and the body focuses mainly on the shaping of the psychological world through the development of imagination and memory. Bruno's works deal with the "Art of Memory", which elevates and gradually extends the consciousness of the disciple of wisdom from the earthly world to the extending boundaries of the starry sky. Bruno supports that humans who process the images of ideas through their imagination can approach the same archetypical ideas found within the divine mind and then embody them without distortions to the material world. These images constitute the best guides to the soul, because they elevate consciousness and facilitate its entry and access to the archetypical ideas found in the universal intellect. As these images dim the light, they prepare the eyes of the soul which are still wrapped in fog to gradually face the very same ideas.
\end{abstract}

Keywords: Philosophy, Renaissance, harmony of the opposites, unity, logic, imagination, memory, psychological world, Heroic Frenzies individual freedom

\section{THE RENAISSANCE}

The characteristics of the historical period called The Renaissance appear in Italy in the $14^{\text {th }}$ century $\mathrm{AD}$ and last until the $16^{\text {th }}$ century $\mathrm{AD}$. Within this period a total renewal of philosophy, science, art and civilization

\footnotetext{
${ }^{1}$ Author's e-mail address: Jfikas@ otenet.gr
} 
takes place. Renaissance ideas are not theocentric like the ones in the Middle Ages, but focus mainly on humans, city and nature. A new society characterized by mobility and conquest succeeds the static society of the Middle Ages with the strict secular and religious authority.

The Renaissance human is able to arrange his life, shape his future and change his environment through the development of his personal virtues. The representatives of that new Renaissance spirit wanted to overcome the contradictions and conflicts of their times in order to create a better world. That need for change urged them to seek for ideals in the classical world. Literature, arts, science, politics and philosophy were cultivated. The ancient intellect returned through philosophy; while myths and symbols reappeared through art and mainly painting.

\section{REPRESENTATIVES OF THE RENAISSANCE}

The main Renaissance representatives on philosophy were: Marsilio Ficino (1433-1499), Pico della Mirandola (1463-1494), Giordano Bruno (1548-1600) and Tommaso Campanella (1568-1639). With regard to art, they were Botticcelli (1445-1510), Leonardo Da Vinci (1452-1519), Raphael (1483-1520), Michelangelo (1475-1564), Tiziano (1490-1576), Tintoretto (1518-1594) and Paolo Veronese (1528-1588). The artist and the philosopher, genuine representatives of the Renaissance spirit, harmonize the antitheses between logic and imagination, philosophy and religion, individual freedom and secular order.

\section{LIFE AND WORK OF GIORDANO BRUNO}

Giordano Bruno was born in Nola, near Naples, in 1548. He entered the Dominican Order and, following publication of some works that are now lost, he left Italy in 1579 for Switzerland, France and eventually England, a move perhaps due to the oppressive climate in his own country, where the church felt itself threatened by the new science which he attempted to propagate. Having acquired a great interest in Ramon Lull (1232-1316) and the art of memory, he presented in London his vision of an infinite universe in which he sought to re-unify terrestrial physics with celestial physics on 
the basis of a principle of universal becoming. He also reflected on the causes of the religious wars and tried to determine the origin of the theological disputes of the period. Beginning with the metaphysics expressed in De la causa, principio e uno (Cause, Principle and Unity), which reflected the objections he encountered in England, he derived a new concept of the divinity which evolved from his cosmology. The magical, animistic vision of everything which he adopted throughout all his writings, not just those of the last period of his life, is evident here. In addition to his specific contributions to the scientific revolution, he presented a general metaphysical vision that contributed significantly to the development of Renaissance philosophy. ${ }^{2}$

La Cena de le Ceneri (The Ash Wednesday Supper) was the first of the dialogues in Italian which Bruno published in 1584/85. The striking feature of this work, in which the author proclaims his Copernicanism, is the immediate connection established between the annual motion of the earth around the sun and the infinity of the universe. This, however, was quite different from the position of Copernicus, who, having given new dimensions to the traditional cosmos, recognized the immensity of the heavens but left to the natural philosopher the ultimate decision about whether or not the universe was infinite. In The Ash Wednesday Supper, on the contrary, we find a clear affirmation of an infinite universe with infinite solar systems similar to our own. Suns and earths are composed of our own elements, they are living and inhabited beings, they are stars which are recognized not only as living things but also as divinities. ${ }^{3}$

The first works of Bruno in England, entitled Explicatio Triginta Sigillorum and Sigillus Sigillorum (Thirty Seals and The Seal of Seals), are about exercising memory as a basic tool for human education. The rest of his works, of that same period (1583-1585), which is considered to be his most prolific one, are mainly characterized by philosophical dialogues. In his cosmological works Cena dele Ceneri and Dela Causa, Principio e Uno (The Ash Wednesday Supper and Cause, Principle and Unity), Bruno praises

\footnotetext{
${ }^{2}$ Bruno, G., Cause, Principle and Unity: Essays on Magic, Introduction, Cambridge University Press, 1998, p. vii.

${ }^{3}$ Bruno, G., Cause, Principle and Unity: Essays on Magic, Introduction, Cambridge University Press, 1998., p. viii.
} 
Queen Elizabeth; while his moral works Spaccio dela Bestia Trionfante and Degli Eroici Furori (The Expulsion of the Triumphant Beast and The Heroic Frenzies) are dedicated to Sir Philip Sidney, who was a courtier. Sir Philip Sydney along with Michel de Castelnau, ambassador of the king Henry III of France to England, remained strong protectors of Bruno until the end of his life. His two works Dele Infinito, Universo e Mondi and Cabala del Cavallo Pegaseo (The Infinite, the Universe and Worlds and The Cabala of Pegasus) complete his writings in London. ${ }^{4}$

You have no opportunity here to speak of that divine spirit of the earth, of that special and unique Lady, who from that cold sky lying by the arctic parallel spreads such a clear light over the whole terrestrial globe. I mean Elizabeth, who by title and royal dignity is not inferior to any king anywhere on earth. In regard to judgment, wisdom, counsel and governing she is not second to anyone who carries a royal scepter on earth. In the Knowledge of arts, in familiarity with sciences, in understanding and mastering all languages that noted and learned personalities can be heard to speak in Europe, without any contradiction she is superior to all the other princes and rulers of such kind; if the empire of fortune would correspond to and would match the empire of the most generous spirit and mind, (she would be the sole empress of this terrestrial sphere, and with fuller significance that divine hand of hers would sustain the globe golden scepter of this universal monarchy. ${ }^{5}$

During his philosophical tour in Europe in 1588, Giordano Bruno left the city of Wittenberg in Germany and went to Prague. There he tried to get in contact with the emperor Rudolph II, who was interested in philosophy, astrology and alchemy (the philosopher's stone). Bruno dedicated his work Articuli centum et sexaginta adversus huius tempestatis mathematicos atque Philosophos (One Hundred and Sixty Theses Against Mathematicians and Philosophers) to Rudolph. This book includes geometric diagrams used for the understanding of the universe creation. In his book dedication to the emperor, Bruno mentions that he looks forward to

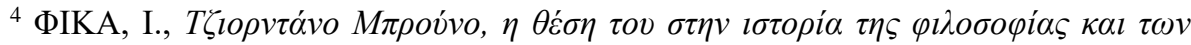

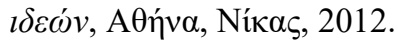

${ }^{5}$ Bruno, G., The Ash Wednesday Supper, S. L. Jaki, The Hague, Mouton, 1975, pp. 82-84.
} 
a new universal religion which will unite all humans under the law of love and will lead nations and societies to peace and amity.

According to F. Yates, it was when Henry of Navarre became King of France that Bruno decided to return to Italy. Bruno believed that it was the right opportunity for a Catholic King to bring about secular reforms within a Catholic framework. When the Venetian patrician, Giovanni Mocenigo, invited Bruno to Venice to teach him the art of memory, Bruno accepted the invitation hoping to convey in Italy the liberating ideas he had managed to spread in the rest of Europe. As reported in Yates, Bruno was preparing a new book on 'The Seven Liberal Arts', when Mocenigo, whom might have been disappointed by the unwillingness of Bruno to teach him the art of memory, denounced him to the Holy Inquisition. On May 26, 1592, Bruno was arrested by the Holy Inquisition in Venice, and although its influence was limited, it managed to impose its ideas. Then, in February 1593 Bruno was sent to Rome prisons, where he was held for seven years. His long imprisonment exhausted him both physically and mentally. However, he managed to make the most of the few days that he was given to present himself in court.

The accused philosopher (Giordano Bruno) answered by the following profession of faith, which is that of every disciple of the ancient masters:

"I hold, in brief, to an infinite universe, that is, an effect of infinite divine power, because I esteemed it a thing unworthy of divine goodness and power, that, being able to produce besides this world another and infinite other, it should produce a finite world. Thus I have declared that there are infinite particular worlds similar to this of the earth, which, with Pythagoras, I understand to be a star similar in nature with the moon, the other planets, and the other stars, which are infinite; and that all those bodies are worlds, and without number, which thus constitute the infinite universality in an infinite space, and this is called the infinite universe, and of a multitude of worlds. Indirectly, this may be understood to be repugnant to the truth according to the true faith.

Moreover, I place in this universe a universal Providence, by virtue of which everything lives, vegetates and moves, and stands in its perfection, and I understand it in two ways; one in the mode, in which the whole soul is present in the whole and every part of the body, and this I call nature, the shadow and footprint of divinity; the other, the ineffable mode in which 
God, by essence, presence, and power, is in all and above all, not as part, not as soul, but in mode inexplicable.

Moreover, I understand all the attributes in divinity to be one and the same thing. Together with the theologians and great philosophers, I apprehend three attributes, power, wisdom, and goodness... "6

Giordano Bruno with courage answered to his judges. "It is you who tremble more as you read me this sentence that I on hearing it". ${ }^{7}$

\section{THE UNIVERSE}

Giordano Bruno believed that God is the one to move humans, gods move the celestial bodies and the stars, the stars move the spirits of nature, which in their turn form the compounds of the natural elements; these elements activate the senses, the senses influence the soul and the soul influences the whole living creature. This is the downward course of the scale. However, the living creature escapes through the senses to the compounds, through the compounds to the various elements and through them to the spirits that inhabit them, through the spirits to the stars, through the stars to gods and through gods to the admiration of the unique, simplest, supreme and absolute Being. In this way, the descent from God to the living creature through the world takes place and the living creature's ascent to God through the world.

Moreover, Giordano Bruno believed that the earth is a living entity who "senses" in a different way from that of a human. They had observed that the rotary movement of the Earth around the sun in vigorates its energy and vitality as well as the beings living in it. During the vernal equinox, the autumnal and summer energies refresh themselves and so does the natural vitality of the planet. During the autumnal equinox, the energies that help in

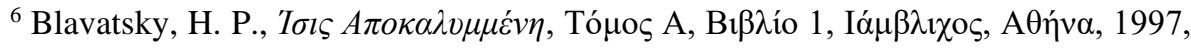
pp. 226-227.

${ }^{7}$ YATES, Fr. Giordano Bruno and the Hermetic Tradition, London, The University of Chicago Press, 1964. Livraga, J., The Alchemist, Paperback, 2001.
} 
the development of the psychological and the mental world are refreshed, while the natural vitality on the planet decreases. ${ }^{8}$

\section{THE HARMONIZATION OF OPPOSITES}

Giordano Bruno believed that harmony appears wherever there are opposites. In his work The expulsion of the Triumphant Beast, he mentions typical examples which verify this theory. "Thereby work pleases us only after rest and rest pleases us only after work. People who live in the countryside desire to go to the city and those who live in cities desire to go to the countryside for rest and holidays. Walking satisfies the person who rested and the one who has walked a lot finds rest relieving. Thus, the transition from the one extreme to the other, this motion through intermediary situations is what pleases us more. The person who wants to overcome a great obstacle which is in front of him should take several steps backwards".

Bruno used opposite pairs in his work The Ash Wednesday Supper as well, to convey the duality of human nature: "grand and small, cheerful and angry, bitter and happy, tragic and comical, heroic and dejected, teacher and student, believer and unbeliever, facile and ponderous, cringing and liberal, apish and dignified, a sophist with Aristotle, a philosopher with Pythagoras, smiling with Democritus, crying with Heraclitus". 9

\section{THE HEART AND THE MIND}

In his work The Ash Wednesday Supper, Giordano Bruno encourages the cultivation of philosophy which harmonizes the heart with the mind, the power with wisdom. In a poetic manner he presents the King of France, Henry III, as a model human who has walked the road to heart. Bruno actually mentions that Henry III is the king "who from the most generous heart of Europe makes the farthest corners of the world resound

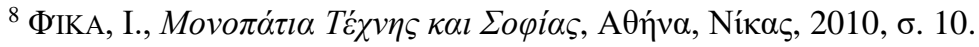

${ }^{9}$ Bruno, G., The Ash Wednesday Supper, S. L. Jaki, The Hague, Mouton, 1975, pp. 43-44.
} 
with the voice of his fame. He, when trembling with anger as a lion in a deep cave, casts fright and deadly fear on the other powerful predators of these forests; and when he retires and takes rest, he sends out such a blaze from a liberal and kindly soul, which kindles the neighboring tropics, warms the icy Great Bear, and dissipates the rigor of the arctic desert which revolves under the eternal custody of the fiery Bootes. VALE". ${ }^{10}$

In the same work, Bruno praises the human who cultivated the divine mind, the voice of silence, who whispers to the inner ears of the human and who encourages him to rise upwards to the spiritual world. Bruno states, "Now here is he who has pierced the air, penetrated the sky, toured the realm of stars, traversed the boundaries of the world, dissipated the fictitious walls of the first, eighth, ninth, tenth spheres, and whatever else might have been attached to these by the devices of vain mathematicians and by the blind vision of popular philosophers. Thus aided by the fullness of sense and reason, lie opened with the key of most industrious inquiry those enclosures of truth that can be opened to us at all, by presenting naked the shrouded and veiled nature; he gave eyes to moles, illumined the blind who cannot fix their eyes and admire their own images in so many mirrors which surround them from every side. He untied the tongue of the mute who do not know [how to] and did not dare to express their intricate sentiments. He restored strength to the lame who were unable to make that progress in spirit which the ignoble and dissolvable compound [body] cannot make. He provided them with no less a presence [vantage point] than if they were the very inhabitants of the sun, of the moon, and of other nomadic [wandering] stars [planets]. He showed how similar or dissimilar, greater or worse [smaller] are those bodies [stars, planets] which we see afar, compared with that [earth] which is right here and to which we are united. And he opened their eyes to see this deity, this mother of ours, which on her back feeds them and nourishes them after she has produced them from her bosom into which

${ }^{10}$ Bruno, G., The Ash Wednesday Supper, S. L. Jaki, The Hague, Mouton, 1975, p. 22. 
she always gathers them again -- who is not to be considered a body without a body without soul and life". ${ }^{11}$

\section{BEAUTY LOVE AND EUDAIMONIA}

Giordano Bruno, like Marsilio Ficino and Pico della Mirandola, believed that beauty is the manifestation of a radiant beam, which shines through the senses on the soul and the mind of humans and activates imagination. Beauty prepares the soul to fulfill an ascending course towards wisdom in the same way that aesthetics leads to ethics. The natural beauty is the step that leads humans to love, which characterizes the psychological world, and ultimately, to eudaimonia, which characterizes the spiritual world. For Renaissance philosophers, beauty is the way through which artists and mainly painters and poets try to express the truth and captivate a beam of light which will turn the profane work into sacred work.

\section{IMAGINATION AND MEMORY}

\section{Imagination}

For Giordano Bruno, humanity is a link of an evolutionary chain which starts with the mineral world, the plant and animal world and the human world and continues with heroes and gods. Bruno believed that the human soul needs molding and cultivation so that it can harmonize with the mind and the body.

Bruno's philosophical theory on the harmonization of the soul with the mind and the body focuses mainly on the shaping of the psychological world through the development of imagination, memory, attention and concentration. His works De Umbris Idearum, Cantus Circaeus, Explicatio Triginta Sigillorum, Sigillus Sigillorum, Lampas Triginta Statuarum, De Imaginum, Signorum, et Idearum Compositione deal with the art of memory

\footnotetext{
${ }^{11}$ Bruno, G., The Ash Wednesday Supper, S. L. Jaki, The Hague, Mouton, 1975, p. 61.
} 
and encourage humans to mold their psychological world in order to approach the spiritual one.

Bruno supported that humans who process the images of ideas through their imagination can approach the same archetypical ideas found within the divine mind and then embody them without distortions to the material world. These images constitute the best guides to the soul, because they elevate consciousness and facilitate its entry and access to the archetypical ideas found in the universal intellect. As these images dim the light, they prepare the eyes of the soul which are still wrapped in fog to gradually face the very same ideas. According to Bruno, the archetypical image of the god Hermes can be depicted with the image of a statue of the god, like the Hermes of Praxiteles, imprinted on memory and moreover, interrelated with the quality characteristics of the god Hermes, such as the magic perception, eloquence, skillfulness etc. The archetypical image of Aphrodite can be depicted with the image of a statue of the goddess, like the Aphrodite of Milos, imprinted on memory and interrelated with the quality characteristics of the goddess Aphrodite, which are beauty, love, abundance. $^{12}$

\section{Memory}

Bruno believed that knowledge is the mere recollection of ideas and identified three types of memory: the natural memory which deals with the world of the body, the psychological one dealing with the world of the soul and the superior memory with the world of the mind. Bruno believed that when imprinted on the psychological memory the images of the sensory objects activate memory; and hence, a bridge is built between the spiritual and the material world.

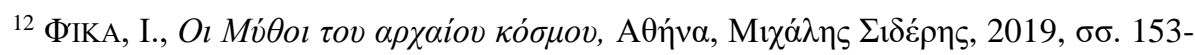
154. 


\section{THE HEROIC FRENZIES. IMAGES AND SYMBOLS}

In his work Gli Eroici Furori Bruno refers to the myth of Actaeon, the young hunter who dared to face the goddess Diana swimming naked in the clean waters of a spring. The goddess punished him by turning him into a stag, which was devoured by his own blood hounds. While in all kinds of hunt the hunt recaptures his prey, in the hunt of spiritual purity symbolized by the naked Diana, the hunter himself is captured. The stag symbolizes the sacred and pure ideals, while Actaeon's dogs symbolize the mental judgment and will which help him to pass from the natural world, the world of multiplicity, to the spiritual world, the world of truth and unity. ${ }^{13}$ In the same work, Bruno mentions a triad of perfections, which are truth, wisdom and intellect. In humans, these three notions are expressed as will, love and intellect. The symbolic images that Bruno uses to depict these three perfections are the images of the captain, phoenix and blacksmith respectively. The captain is the human will, which, as Bruno mentions, stands on the stern of the soul with the small wheel of logic and intellect governing the wishes of the inferior human powers. With the clarion sound the captain calls all the warriors, all the active powers of humans to fight the inferior passive ones, the ones of natural limitations. According to Bruno, the phoenix symbolizes the active intellect, the spiritual one, with which the hero senses the divine things and unites himself with the universe. ${ }^{14}$ The blacksmith expresses the human altruistic intellect, which intervenes with the anvil, the hammer and the fire and purifies the inferior intellect, which Bruno likens to the Hephaestus furnace where ideas are forged. ${ }^{15}$

${ }^{13}$ Bruno, G., Gli Eroici Furori, Biblioteca Rara, Milano, Puplicata da G. Daelli, p.

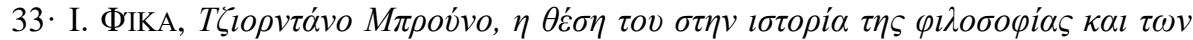

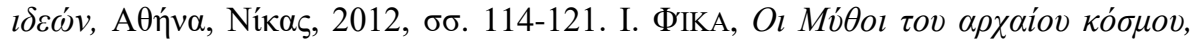

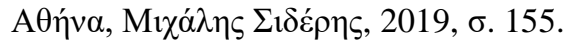

${ }^{14}$ Bruno, G., Gli Eroici Furori, Biblioteca Rara, Milano, Puplicata da G. Daelli, p. 106.

${ }^{15}$ Bruno, G., Gli Eroici Furori, Biblioteca Rara, Milano,Puplicata da G. Daelli, p. 117. 


\section{THE “ART OF MEMORY” THE CONVERSION OF MAN INTO GOD}

The correspondence of virtues with constellations in the work The Expulsion of the Triumphant Beast constitutes a mnemonic system by Bruno, which elevates and gradually extends the consciousness of the disciple of wisdom from the earthly world to the extending boundaries of the starry sky. In the same work there is a second mnemonic system in which Bruno correlates the various parts of the human body, of the microcosm, which is a miniature of the macrocosm, with virtues. "I say, indeed, that their heads should contain a bridled imagination, cautious thinking, and a retentive memory. Their foreheads should show a quick apprehension, their eyes, prudence, their noses, sagacity, and their ears, attention. There should be truth on their tongues, sincerity in their breasts, and well directed affections in their hearts. In their shoulders they should show patience, in their backs, forgiveness of wrongs received, in their stomachs, discretion, in their belies, temperance, in their breasts, continence, in their legs, constancy, and in the soles of their feet rectitude. In their left hands, they should hold the Pentateuch of Decrees; in their right hands, discursive Reason, informative Knowledge, regulating Justice, governing Authority, and executive Power"l6.

In a third pursuance of the mnemonic system in his work Lampas Triginta Statuarum ${ }^{17}$, Bruno presents the images of gods and their quality characteristics found both in Bruno's work and the orphic hymns. According to Bruno, the frequent contact of the soul with the gods arouses within the philosopher and the artist the desire to acquire the quality characteristics of gods. ${ }^{18}$

\footnotetext{
${ }^{16}$ Bruno, G., The Expulsion of the Triumphant Beast, trans. A. Imerti, University of Nebraska Press, 1992, p.92.

17 Bruni, J., Lampas triginta statuarum, Opera latine concripta, F. Tocco et H. Vitelli, Faksmile-Neudruck der Ausgabe von Fiorentino, Tocco und Anderen, Neapel und Florenz, 1879-91, pp. 9-37.

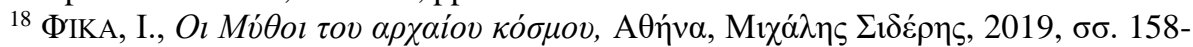
161.
} 
In his work entitled Sigillus Sigillorum ${ }^{19}$, Bruno provides supplementary instructions on the constant and laborious effort required in parallel with memory practice so that the human shapes his psychological world and approaches his spiritual one. Therefore, the first important factor, of the fifteen that Bruno highlights, is the influence of the environment. In fact, he initially suggests a "renunciation" of the environment with the intention of spiritual perfection. Other factors are: the challenges that cause pain but perfect the human being; the recognition of the soul world; the preoccupation with spiritual activities and the parallel reduction in sleep time; the supremacy of the intellect over the body; the ascertainment that the intellect leads an independent life from the body; Plato's belief that the forms of objects exist within the soul world, the intellect, before they manifest themselves in the world; the realization that there is a relation between the external and internal world; the influence of the emotional world on the soul and therefore, the need for strong self-control; the influence of the soul on the environment; the dissociation from the animal habits; the avoidance of emotions, such as sadness, melancholy and fantasy, which cause great turmoil in the soul; the conviction that logic is not enough to seek the truth; the bad mood that sets the conditions for deficiency in philosophical attitude; and the philosophy that elevates humans. ${ }^{20}$

\section{CONCLUSION \\ TOWARDS A NEW RENAISSANCE}

The rediscovery of the Renaissance philosophy will help man, to be aware of his potentials, to identify his own core values, to acquire a vital and integrated sense of self, to become better and wiser citizen that will contribute to the common good, to acquire a holistic vision of the universe, to rediscover nature, create new relationships with it and develop a consciousness of responsibility and accountability towards nature.

19 BRUnI, J., Sigillus Sigillorum, Opera latine concripta, F. Tocco et H. Vitelli, Faksmile - Neudruck der Ausgabe von Fiorentino, Tocco und Anderen, Neapel und Florenz 1879-91, pp. 181-187.

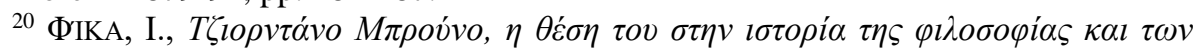

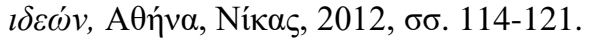




\section{REFERENCE LIST}

Adamou - Fika K., Ideal States from Plato to Campanella, Athens, Academy of Athens, 2006.

Boccaccio, G., Il Decamerone, F. Palazzi, Milano, Edizioni D’ Arte, 1964.

Bruno, G., Cause, Principle and Unity, R. J. Blackwell - R. de Lucca, Cambridge, Cambridge University Press, 1998.

Bruno, G., On the Compositions of Images Signs and Ideas, trans. Ch. Doria, D. Higgins, New York, Willis, Locker \& Owens, 1991.

Bruno, G., The Ash Wednesday Supper, trans. S. L. Jaki, The Hague, Mouton, 1975.

Bruno, G., The Expulsion of the Triumphant Beast, trans. A. Imerti, University of Nebraska Press, 1992.

Bruno, G., The Heroic Frenzies, P. E. Memmo, Chapel Hill, University of North Carolina Press, 1964.

Fikas Y., World, City, Man, philosophical texts, Nikas, Athens, 2016.

Fikas Y., Giordano Bruno, his place in the history of philosophy and ideas, Nikas, Athens, 2012.

Fikas Y., Paths of Art and Wisdom, Nikas, Athens, 2010.

Livraga, G., El Alqimista, Editorial Cunillera, 1974.

Schwarz, F., Ohmann I. The spirit of the Renaissance, Austria Filosofica Graz, 2005.

Yates, Fr., Giordano Bruno and the Hermetic Tradition, Chicago, The University of Chicago Press, 1964.

Yates, Fr., The Art of Memory, Chicago, The University of Chicago Press, 1966. 


\section{JANIS FIKAS \\ BCA koledž, Atina, Grčka \\ ĐORDANO BRUNO, NJEGOVO MESTO U ISTORIJI FILOZOFIJE I IDEJA}

Sažetak: Cilj ovog rada jeste da predstavi renesansnog filozofa Đordana Bruna. Prema Đordanu Brunu, ljudsko biće čine tri momenta: telo (soma), duša (psyche) i duh (nous). Brunova filozofska teorija o harmonizaciji duše s umom (nous) s jedne i tela s druge strane, fokusira se uglavnom na oblikovanje psihološkog sveta kroz razvijanje mašte i pamćenja. Brunova dela bave se „veštinom pamćenja”, koja uzdiže i postepeno proširuje svest pristalica mudrosti od zemaljskog sveta do širećih granica zvezdanog neba. Bruno podržava da ljudi koji obrađuju slike ideja svojom maštom mogu pristupiti istim arhetipskim idejama koje se nalaze unutar božanskog uma i potom ih oteloviti bez izobličenja u materijalnom svetu. Te slike čine najbolje vodiče duši, jer uzdižu svest i olakšavaju njen ulaz i pristup arhetipskim idejama koje se nalaze u univerzalnom intelektu. Kako ove slike prigušuju svetlo, one pripremaju oči duše - koje su još uvek obavijene maglom - da se postepeno suočavaju s tim istim idejama.

Ključne reči: filozofija, renesansa, harmonija suprotnosti, jedinstvo, logika, mašta, pamćenje, psihološki svet, herojske pomame individualne slobode 
